\title{
DEVELOPMENT OF ENTERPRISE COMPETENCIES AT LITHUANIAN ACADEMY OF PHYSICAL EDUCATION
}

\author{
Birutè Mažutaitienė, Ramutė Vaznonienė, Asta Lileikienė \\ Lithuanian Academy of Physical Education, Kaunas, Lithuania
}

Birutė Mažutaitienè. Master of Education Science. Lecturer at the Department of Languages at the Lithuanian Academy of Physical Education. Scientific field of research — quality improvement in university teaching.

\begin{abstract}
The article deals with the problems of university teaching. It analyses the possibility to improve the quality of traditional university teaching by introducing enterprise competencies and making them one of the outcomes of learning.

The authors present the results of the research that has been carried out using a method of a questionnaire at the Lithuanian Academy of Physical Education. The aim of the study was to investigate the development of enterprise competencies in undergraduate population. The research was conducted in the Faculty of Sports Technologies and Tourism at the Lithuanian Academy of Physical Education. The randomly selected sample consisted of 131 second and fourth year students of sports and tourism management. The data obtained helped to draw the following conclusions: traditional teaching methods prevail at the Lithuanian Academy of Physical Education; in the process of university studies students pay greater attention to theoretical knowledge than to the acquisition of practical skills; the second and the fourth year students of sports and tourism management lack systematic development of enterprise competencies in the process of teaching. In the scale of importance, the most appreciated enterprise competencies are as follows: ability to communicate, computer literacy, knowledge of one's capabilities, ability to work in a team; accordingly, the least appreciated enterprise competencies are as follows: ability to seek and to act on new opportunities, ability to analyse statistical data, ability to eliminate stressors, managing personal stress and stressful situations.
\end{abstract}

Keywords: quality, university teaching, enterprise competencies.

\section{INTRODUCTION}

$\mathrm{P}$ roblems of teaching and learning in higher educational institutions and especially those related to their quality improvement have been discussed by many authors (Jordan, 1997; Tate, 1996; Ramsden, 1992; Elton, 1990; Barnett, 1989; Hutchinson, Waters, 1987). In the development of teaching process T. Hutchinson (1987) and R. R. Jordan (1997) emphasize the importance of learning, especially its independence, individualization and self-direction. According to S. Griffiths (1996) the key determinants of quality improvement are the staff development and teacher training. In G. Gibb's (1990) opinion teaching styles are responsible for qualitative teaching. R. Ramsden (1992) maintains that the best way to improve the quality of university teaching is to study qualitative differences in student learning. Authors like A. Tate (1996) and R. Barnett (1989) suggest that qualitative university teaching should develop student's intellectual and imaginative powers focusing on educationally-based skills. However, there can be no correct answer how to solve the issue of improving the quality of teaching, as different authors emphasize different aspects of the teaching process.

The concept of excellence of teaching in higher education has always been discussed by scientists but it has surprisingly unchanged throughout the years. In 1929 A. N. Whitehead in his essay "Universities and their function" described his view of the aims for student learning of an 
institution of higher education. A. N. Whitehead's main theme was that university education should be 'relevant' to the community and the economy and it should lead students to the 'imaginative acquisition of knowledge'. P. Ramsden (1992) suggests that the way to improve teaching is to study our students' experiences of learning, to think carefully about our students' understanding of the subject matter and their reactions to how it is taught and how they are able to apply this knowledge in a variety of different strategies.

Whenever the improvement of quality in university teaching is discussed, it has become customary over the years to focus attention on the person and the process: teaching styles, content, organization, presentation, appropriate use of teaching aids, etc. The authors of this paper suggest improving the quality of university teaching by introducing enterprise competencies in undergraduate population. The Enterprise in Higher Education Initiative is a program initiated by the Manpower Services Commission in 1987 (Tate, 1996), which has stated that every person seeking higher qualification should be able to develop competencies and aptitudes relevant to enterprise. It is not really an issue of knowledge or academic standards, more an issue of empowering students to put that knowledge into action.

The object of the study is the development of enterprise competencies in university teaching as one of the means of improving teaching and learning.

The aim of this paper is to analyse the development of enterprise competencies and the views of students on the quality of teaching at the Lithuanian Academy of Physical Education. To discuss the following problem, the authors of the article set the following objectives:

1. To discuss the necessity of enterprise competence development in university teaching.

2. To analyse the peculiarities of enterprise competence development at the Lithuanian Academy of Physical Education.

\section{METHODS OF INVESTIGATION}

The methods of the study - the analysis of the research literature, the questionnaire-based inquiry, the method of statistical analysis.

Methodology of the research is based on the following theoretical concepts:

1. Openness and critical approach to new ideas and initiatives, constant quality improvement in studies and research, adequate and dynamic response to the real needs of community (Vision Statement of the Lithuanian Academy of Physical Education).

2. Every person seeking a higher education qualification should be able to develop competencies and aptitudes relevant to enterprise (Tate, 1996).

Of course, the notion of competence is taken from management theories and is defined as 'underlying characteristics of a person which results in an effective performance in a job' (Boyatzis, 1982). Enterprise is defined as the ability to think of new activities or ideas and make them work (Dictionary of Contemporary English, 1995). However, learning through enterprise is important in higher education what means the effective delivery of the enterprise competencies.

The abilities most valued in industrial, commercial and professional life are the transferable intellectual and personal skills. These include the ability to analyse complex issues, identify the core of a problem and the means of solving it, to synthesize and interpret disparate elements, to clarify values, to work cooperatively with others, to communicate clearly and others. A Higher Education System which provides its students with these things is serving society well (Tate, 1996).

Introduction of enterprise competencies in the educational process feeds into the existing problem of "graduateness" and employability of graduates which focuses on the skills graduates need to improve their labour-market forces.

The main method of the study was a questionnaire-based inquiry which was built up in accordance with the University of Ulster's Program 'Enterprise in Higher Education' (Tate, 1996). The validity of the questionnaire was tested with the group of 34 students during a pilot study (October, 2003). The survey was conducted in December, 2003. The questionnaire used in the research was formulated by the Department of Kinanthropology and Sport Development at the Lithuanian Academy of Physical Education (LAPE). The competencies included into the questionnaire were the following: communication, leadership, teamwork and followership, negotiation and persuasion, problem analysis and solving, decision-making, creating opportunities, achievement drive, risk-taking, self-awareness, 
coping with and managing personal stress and stressful situations, dealing with conflict, flexibility, being proactive, numeracy, computer literacy. The questionnaire was separated into 3 parts. The first part aimed to find out students' subjective self-evaluation on their competency level. The purpose of the second part was to collect information on the views of students about the appliance of acquired enterprise competencies in their future career. The third part of the questionnaire provided the respondents' evaluation of the teaching process as a framework for the development of enterprise competencies.

The research included a survey of a representative sample of full-time students attending an institution of higher education. The study had an aim to reveal the progress of students' experience and the change in their attitudes. Only students in their second and fourth year were surveyed because the first year students would have limited experience of higher education to report about in their first term. The mix of students enabled us to compare and contrast the experiences of the second and the fourth year students. The randomly selected sample of full-time students was drawn from the LAPE selecting students most in need of enterprise competencies - sports and tourism management entrants. A total of 131 usable questionnaires was received, 81 from the second year students and 50 from the fourth year students. The data obtained was compiled and investigated using a computer statistical worksheet "Microsoft Excel 2000". Difference variability was assessed by Stjudent criterion and was significantly reliable when $\mathrm{p}<0.05$.

\section{RESULTS OF THE STUDY}

The primary aim of the research was to clarify whether the students are satisfied with their studies at the Lithuanian Academy of Physical Education (LAPE) (Fig. 1).

The results of the study showed that the major part of the second and the fourth year students couldn't give a yes-no answer to the question if they are satisfied with their studies at the Lithuanian Academy of Physical Education. But it is obvious (Fig. 1) that the fourth year students tend to evaluate the studies worse than the second year students. The difference is statistically relevant $\left(\chi^{2}=9.14 ; p<0.05\right)$.
The subsequent step in the research was to clarify if the students were seeking for opportunities to get employed in the sphere of

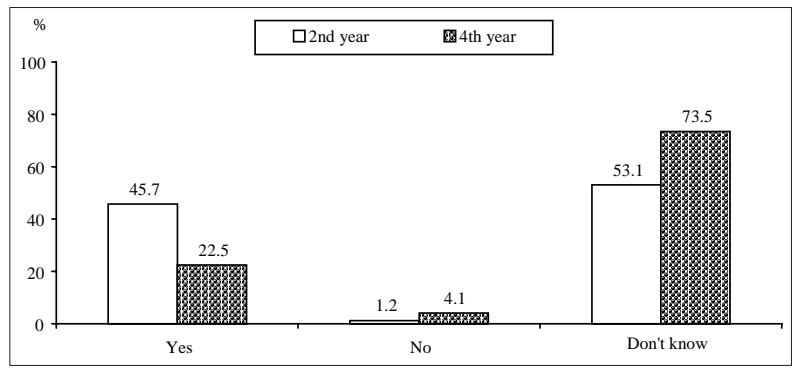

Fig. 1. Students' satisfaction with the studies at LAPE

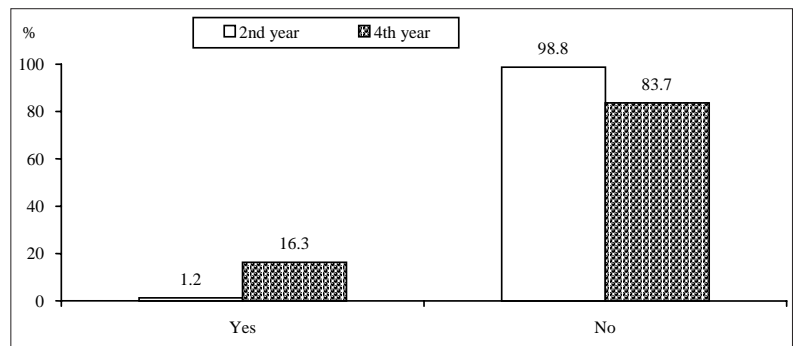

Fig. 2. Results of answers to the question "Are you working in the sphere of tourism and sport?"

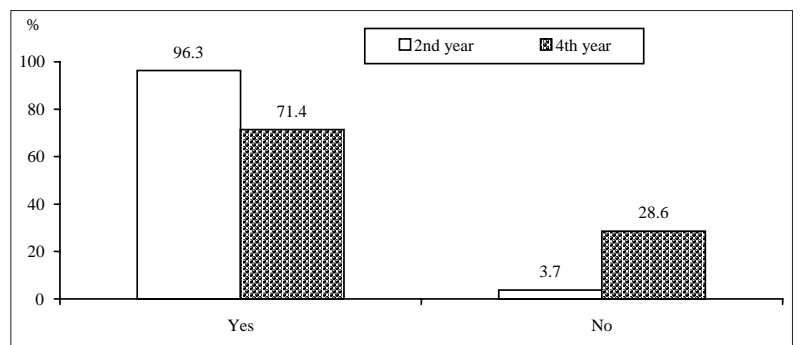

Fig. 3. Results of answers to the question "Are you going to work in the sphere of tourism and sport?"

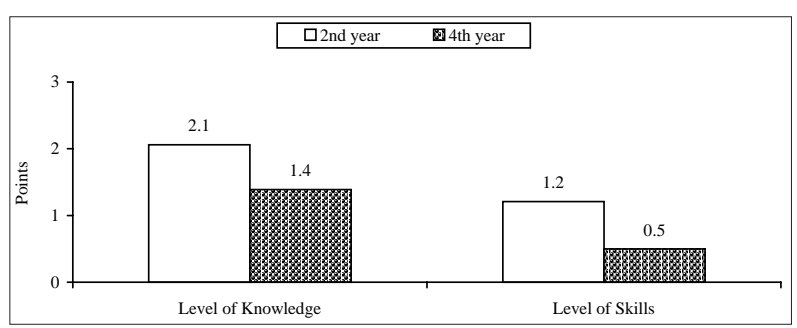

Fig. 4. General evaluation of the level of knowledge and skills acquired at LAPE ( -5 - very low; +5 - very high)

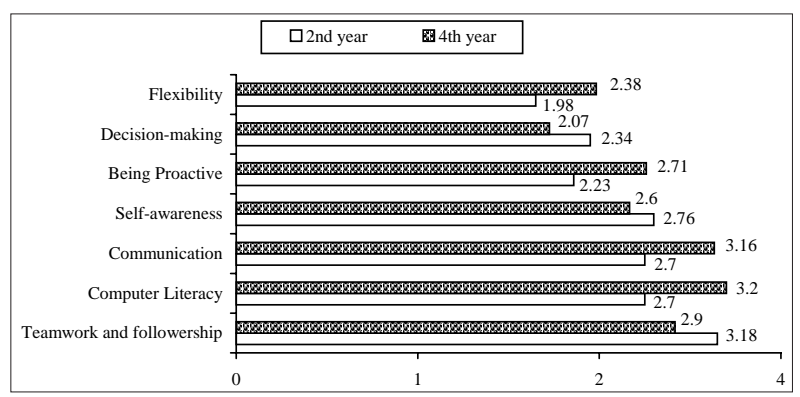

Fig. 5. Evaluation of enterprise competencies acquired at LAPE (7 most appreciated competencies) 
tourism and sport studying at the Academy and if they are going to work in this sphere in the future (Fig. 2,3). The second figure shows that twothirds of the students have never tried to find a job they are being trained for. As a matter of fact, there is a greater number of students working in the sphere of tourism and sport among the fourth year students than among the second year students $\left(\chi^{2}=13.93 ; \mathrm{p}<0.01\right)$. However, as far as students' intentions to do the job they are being trained for in the future are concerned, we notice a different situation - a greater number of the second year students intend to work in the sphere of tourism and sport (Fig. 3) $\left(\chi^{2}=20.23\right.$; $\mathrm{p}<0.001)$.

The next step of our investigation was to clarify the students' opinion about the knowledge and skills obtained at the Lithuanian Academy of Physical Education. For this reason the respondents were asked to evaluate the level of knowledge and skills using a 10-point scale ( -5 - very low; +5 - very high). As we can see from the results in Fig. 4, the fourth year students' opinion in this respect differed from the second year students' opinion, who think that the knowledge and skills received at the Academy are of higher level, while the former group of respondents gave less favourable appreciation. In both cases the difference is statistically relevant $(\mathrm{p}<0.001)$.

In order to investigate the development of enterprise competencies at the Lithuanian Academy of Physical Education, the respondents were asked to evaluate the enterprise competencies acquired during their studies (Fig. 5, 6).

The questionnaire included 17 enterprise competencies, and the second year students most appreciated the following ones: the ability to work in a team, understanding computers and their use, the ability to communicate, knowledge of one's capabilities, and initiative and persistence. The fourth year students were of similar opinion; however, in their answers such competencies as computer literacy and communication received more favourable evaluation than teamwork and followership (Fig. 5).

The fourth year students pointed out the following least appreciated enterprise competencies: the ability to seek and act on new opportunities, the ability to analyse statistical data, the ability to eliminate stressors, managing personal stress and stressful situations. The second year students' answers were rather similar, except the fact that in their answers the ability to eliminate stressors received the least appreciation (Fig. 6).

In order to find out the students' general level of enterprise competence developed at the Academy, the respondents were asked to critically evaluate their abilities (Fig. 7). Students' answers revealed that they rather positively evaluated their enterprise competence developed during the study years: the second and the fourth year students' evaluation was 2.09 and 2.02 points respectively on a 10 -point scale (from -5 to +5 points). The difference between the courses was statistically irrelevant.

\section{DISCUSSION OF THE RESULTS OF THE STUDY}

The research sought information on students' attitudes and experiences of higher education concerning the development of enterprise competencies in the study process. The data obtained showed that the second and the fourth year students were satisfied with their studies in general irrespective of the course they were doing. However, the fourth year students tend to evaluate their studies worse. This difference in students' experience could be associated with the subjects they studied. It is obvious that the fourth year students had more speciality-based subjects

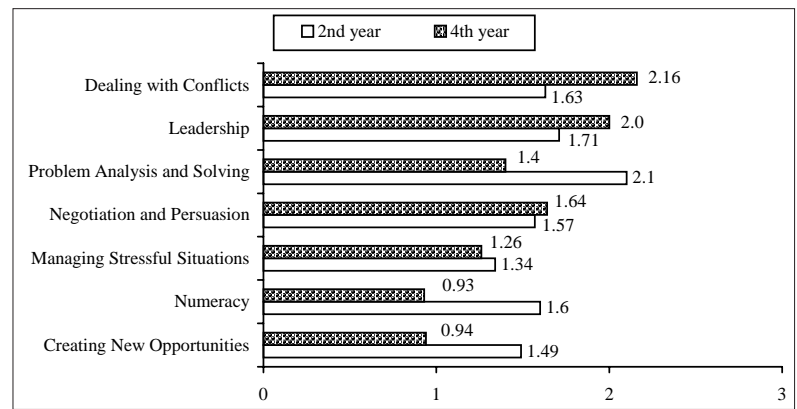

Fig. 6. Evaluation of enterprise competencies acquired during the studies at LAPE (7 least appreciated competencies)

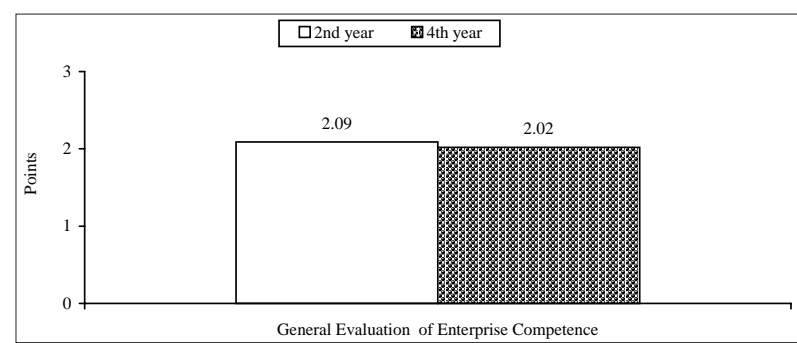

Fig. 7. General evaluation of enterprise competence 
which might not have fulfilled their as future managers' expectations. Also, this group of students had already had work experience in real economic setting - internship in tourism and sport organizations, which might have revealed the lack of practical skills and experience to function in them.

Students were critical of the level of knowledge and skills acquired at the LAPE. Some of their dissatisfaction could be associated with the resource constraints and the teaching methods which have resulted from these. The fourth year students who had more educational experience were even more critical. Thus, students in higher education want to acquire such knowledge and skills which will equip them for the workplace as well as for life. In practice, this could be achieved by introducing enterprise competencies in curriculum development, encouragement of project-based work in real economic settings outside the university (Tate, 1996).

The most important issue of the research was to see how these findings feed into the existing problem of "graduateness" and employability of graduates. And how do they relate to students' desire to improve their labour-market prospects? Perhaps the most telling finding was that students were the least likely to report an improvement in competencies, especially those competencies particularly valued by employers: dealing with conflicts, leadership, problem analysis and solving, negotiation and persuasion, managing stressful situations.

Undoubtedly, students evaluated enterprise competencies on the basis of study programs. The majority of students had not been employed before in the sphere of tourism and sport and it goes without saying that theoretical knowledge acquisition does not provide the competencies mentioned above. Yet, the majority of the second and the fourth year students felt that all their development of enterprise competencies had improved since starting the studies. They were of the opinion that at the LAPE they acquired such enterprise competencies as the ability to work in team, computer literacy, ability to communicate, decision making skills, initiative and persistence. It is obvious that students' assessment of the competencies was also influenced by the subjects they had studied.

\section{CONCLUSIONS}

Summarizing the research results the following conclusions can be drawn:

1. In the process of university studies students pay greater attention to theoretical knowledge than to the acquisition of practical skills. Generalizing the data obtained, it becomes evident that traditional teaching methods prevail at the Lithuanian Academy of Physical Education.

2. The results of the study evidence that the second and fourth year students of sports and tourism management lack systematic development of enterprise competencies in the process of teaching at the Lithuanian Academy of Physical Education. Consequently, they do not have enough practical skills and experience to function in tourism and sport organizations. Only $83.7 \%$ of the fourth year managers are employed in various tourism organizations. But it is worth noting that two-thirds of respondents will seek for position in the sphere of tourism and sport in the future.

3. The effective delivery of enterprise competencies relies on the development of a new strategy for teaching, learning and assessment. Undoubtedly, students evaluate enterprise competencies on the basis of study programs. The research of peculiarities of enterprise competence development shows that the most appreciated enterprise competencies are as follows: the ability to communicate, knowledge of one's capabilities, the ability to work in a team, computer literacy. Accordingly, the least appreciated enterprise competencies are as follows: the ability to seek and to act on new opportunities, the ability to analyse statistical data, the ability to eliminate stressors, managing personal stress and stressful situations 


\title{
REFERENCES
}

Barnett, R. (1989). Responsiveness and fulfillment: The value of higher education in the modern world. Higher Education Foundation Paper, September.

Boyatzis, R. E. (1982). The Competent Manager: A Model for Effective Performance. New York: John Wiley and Sons.

Dictionary of Contemporary English. The Complete Guide to Written and Spoken English. (1995). Longman Group Ltd.

Elton, L. (1990). Teaching excellence and quality assurance. Paper given to SRHE Conference, December.

Gibbs, G. (1990). Improving Learning Project: Briefing Paper for Participants in the Project. Oxford: The Oxford
Centre for Staff Development.

Griffiths, S. (1996). Staff Development and Quality Assurance: Quality Assurance for University Teaching. Ed. SRHE.

Hutchinson, T., Waters, A. (1987). English for Specific Purposes. Cambridge University Press.

Jordan, R. R. (1997). English for Academic Purposes. Cambridge: Cambridge University Press.

Ramsden, P. (1992). Learning to Teach in Higher Education. London.

Tate, A. (1996). Quality in Teaching and the Encouragement of Enterprise: Quality Assurance for University Teaching. Ed. SRHE.

\section{VERSLUMO GEBE்JIMŲ UGDYMAS LIETUVOS KŪNO KULTŪROS AKADEMIJOJE}

\author{
Birutė Mažutaitienė, Ramutė Vaznonienė, Asta Lileikienė \\ Lietuvos kūno kultūros akademija, Kaunas, Lietuva
}

\section{SANTRAUKA}

Straipsnyje nagrinėjamos universitetinio mokymo problemos, i kurias būtina atsižvelgti tobulinant tradicini universitetini mokymą. Straipsnio autorès siūlo tobulinti universitetinį mokymą ugdant studentų verslumo gebejimus.

Aptariami 2003 metu gruodi Lietuvos kūno kultūros akademijoje anketinès apklausos metodu atlikto tyrimo rezultatai, atskleidžiami verslumo gebejimų ugdymo šioje aukštojoje mokykloje ypatumai, pateikiamos išvados. Tyrimas parodè, kad studentai nepakankamai mokomi verslumo, neturi praktinio darbo patirties. Kita vertus, studijų metu igytų žinių ir igūdžiu vertinimas atskleidè, kad akademijoje vyrauja tradicinès teorinès žinios, nes studentai igytas žinias vertino dvigubai geriau nei igūdžius. Tarp geriausiai vertinamų verslumo gebejjimų, igytų mokantis akademijoje, buvo nurodyti psichologiniai gebėjimai dirbti komandoje, bendrauti ir pažinti save; tarp prasčiausiai - gebejjimai susikurti naujas galimybes, statistiniu duomenu išmanymas, gebejimas valdyti stresą ir stresines situacijas.

Raktažodžai: universitetinis mokymas, mokymo kokybè, verslumo gebejjimai.

Gauta $2004 \mathrm{~m}$. rugsėjo $30 \mathrm{~d}$.

Received on September 30, 2004

Priimta 2005 m. gegužès $18 \mathrm{~d}$.

Accepted on May 18, 2005

Birutė Mažutaitienè

Lietuvos kūno kultūros akademija

(Lithuanian Academy of Physical Education)

Sporto g. 6, LT-44221 Kaunas

Lietuva (Lithuania)

Tel +370 37302663

E-mail bmazutaitiene@yahoo.com 